\title{
Higher Education Systems in Russia and Belarus: A Comparative Approach
}

\author{
L. TITARENKO*
}

\begin{abstract}
*Larisa Titarenko - DSc in Sociology, Professor, Department of Sociology, Belarusian State University; Associated Researcher, Sociological Institute of the Russian Academy of Science. Address: 4, Nezavisimosti Av., Minsk, 220030, Republic of Belarus. E-mail: larisa166@mail.ru
\end{abstract}

Citation: Titarenko L. (2019) Higher Education Systems in Russia and Belarus: A Comparative Approach. Mir Rossii, vol. 28, no 4, pp. 112-127. DOI: 10.17323/1811-038X-2019-28-4-112-127

The modernization of higher education in Russia and Belarus is still topical, despite the numerous changes already made to the higher education systems (HES) of both countries in the post-Soviet period. This article shows the similarities and differences in the practice of developing HES in Russia and Belarus. The analysis is based on statistical materials, an analysis of the literature in both countries, survey data, and in-depth interviews conducted by the author with higher education experts in Belarus in 2018.

The starting point for both countries was the Soviet model of higher education. Over time, each country developed this heritage in its own way. Despite the existence of common features in the organization and management of higher education, today this sphere in Belarus is characterized by more centralized management than in Russia. Centralization finds expression in the greater uniformity of educational programs, university practices, and decision-making.

The article shows that in Russia the regionalization of higher education is proceeding at a faster pace, manifested in the active attraction of foreign students. In Belarus this process has a similar vector, but is progressing more slowly. Internationalization has several directions (European, Eurasian, Asian). Neither country wants to give up national priorities in the integration into the European space of higher education, while the implementation of the Bologna principles is higher in Russia. Regardless of changes in the architecture of higher education, the problems of its quality and student motivation remain on the agenda.

The Belarusian centralization of the HES slightly differs from the Russian one. Both countries are searching for answers to similar global challenges-answers which are suitable for their national socio-economic and political conditions. Russia and Belarus are objectively interested in changes in their HES which will contribute to the effective development of their countries. 
Key words: higher education, changes, Russian Federation, Republic of Belarus, regionalism, integration

\section{Introduction}

In the post-Soviet region higher education systems (HES) have to meet the new demands and serve more functions. Modern universities have to provide knowledge and competences, run the innovative research, generate profits, orient graduates in the labor market, and educate good citizens for the state.

Russia and Belarus are well aware of the new global challenges and understand that global competition includes science, technology and education. The development of science and the HES is considered as important for the scientific and technological development of Russia. In Belarus, educational and scientific tasks are also included in the country's development strategies. In this matter, these countries demonstrate their unity. There is an active search for changes which help to preserve national priorities and combine them with the tasks dictated by global changes. Both countries emphasize that higher education institutions should train modern specialists who will work effectively in the new digitalized sectors of the economy. There are no differences in the overall strategies and goals of the HES of the two countries.

Yet, these countries differ from each other as do their indicators of the global success they have achieved. Almost 25 Russian universities are included in the global top-100 institutions while in Belarus only one higher education institution is in the top-500 [Reyting natsional'nykh system 2018; BGU v mirovykh rejtingakh 2018]. According to the literature, there are problems in both systems which prevent them attaining a higher level of quality in education and increasing the level of human capital within their educational communities [Zborovsky, Ambarova 2019; Novik 2018]. Ratings themselves do not provide higher quality but they indicate the high innovation potential of the HES and the country in general. For this reason, universities compete for ratings to present their potential to the public and potential applicants.

In both countries the presidents determine educational policy. For example, Belarusian law [Kodeks 2011] states that the president has the exclusive right to determine state education policy and guarantee its implementation. All administrative bodies follow this policy and do not perform any independent managerial function. According to this policy, the president appoints rectors, who personally appoint other senior administrative staff. In Russia, the president decided on the merger of the Ministries of Higher Education and Science. He is the key actor in the important changes in higher education, however, high ranking universities have some autonomy in decision-making.

The research question is what the similarities and differences in development of the Belarusian and Russian HES are, and how they are meeting global educational challenges. Firstly, on the basis of the statistical sources of information, the major changes in the HES in two countries will be described "as being about both similarities and differences" [Huisman, Meek, Wood 2007, p. 565]. However, in regard to Belarus and Russia the quantitative comparison of statistics is not enough: the Russian system is the largest in post-soviet region; and it has expanded tremendously. Belarusian HES is much smaller. Therefore, secondly, qualitative analysis (18 expert interviews) is applied to focus on the similarities and differences in the systems. 


\section{General characteristics of higher education systems}

Russia and Belarus have been members of the Union State since 1999. This regional initiative made it possible for citizens of Russia and Belarus to ease the process of admission and study in both countries. This strategy, although being potentially profitable for both states, has not become dominant in the educational sphere of Russia or Belarus.

The literature on this issue in Russia [Froumin, Kouzminov, Semyonov 2014; Akhlestina, Erstein 2019] and Belarus [Belaya kniga 2018; Gaisenok 2018] is diverse. However, comparative studies covering these two systems together are few. A large comparative study of higher education systems in all post-Soviet republics made some years ago [Huisman, Smolentseva, Froumin 2017] gives a vivid picture of the development of higher education in each country, while their comprehensive comparison (including the comparison of HES in Russia and Belarus) is less detailed.

At the beginning of post-Soviet period, Russia and Belarus were under the influence of liberal ideas and common transitional expectations. In Belarus some new liberal ideas always coexisted with attempts by the authorities to preserve the "best practices" of the former Soviet system [Vetokhin 2001]. The first post-Soviet Law on Education authorized the creation of private HEIs (higher education institutions) and the introduction of fees into public HEIs, granted more freedom in choosing the programs and disciplines offered by each HEI and replaced the nomination of university rectors with elections [Zakon 1991]. Like in Russia, in the 1990s many Belarusian academic actors created private HEIs, and many new faculties and specialties in state HEIs were opened. The HES grew quickly trying to meet the increased public demands for its expansion. Nevertheless, the system remained under strict centralized administrative control. A decade later the number of private HEIs started to decline. According to some assessments, the main reason for these changes was political and related to consolidation by the authorities to strengthen their ideological control over higher education and prevent student involvement in political initiatives [Gille-Belova 2015]. Other authors believe that the major reasons were economic and related to the market demands of public universities to maintain a high level of enrollment [Gaisenok 2018]. In the $21^{\text {st }}$ century liberal ideas in education were critically accessed and rejected [Kirvel 2018]. The election of rectors which lasted for a short period of time was replaced by their appointment; academic rights were limited, and labor contracts became dependent on administrative conditions. In general, according to the independent Bologna Committee, by the end of the 2000s, the HES in Belarus experienced a significant lack of academic freedom and university autonomy [Gotovnost' belaruskogo vysshego obrazovaniya 2014]. Such limitations have administrative support at HEIs. For example, in 2018, a high ranking university official during the expert interview expressed his opinion, shared by some other officials, that the "elective method did not bring positive results [...] the appointment method is better [...] because there are no conflicts and competition among the scholars" [Titarenko, Zaslavskaya, Avetisyan, Galikyan, Klimenko, Lebedeva, Melkumyan 2019, p. 67].

Despite the horizontal and vertical differentiation of HEIs in Belarus (opening new public HEIs in small cities, the creation of branches of large state universities in regional centers, etc.) there are no joint universities or joint-stock companies with the foreign partners that are common for Russia. As in Russia [Kuzminov, Semyonov, Froumin 2013, p. 33], the existing branches are specialized in economics, management 
and humanities, offering educational services to students who pay tuition fees. Their number is relatively small in Belarus. Another difference from Russia is the nonexistence of foreign HEI campuses in Belarus, except two Russian HEI branches founded as official cooperative projects between the two countries.

In Russia and Belarus private HEIs are generally smaller, focusing mainly on economics, languages, or business studies. They are often considered to be of lower quality, although there are some important exceptions in Russia where some private schools are very popular and more attractive for those who have lost trust in public institutions - for example, European University in Saint Petersburg.

\section{National data on higher education in Russia and Belarus}

We start with comparison of Russian and Belarusian human capital and the ability of these countries to retain and expand it.

According to the 2018 Statistical update of the Human Development Indices (HDI) and Indicators [Human Development Reports 2018], Russia has a higher rank (49) than Belarus (53) out of 189 countries. The educational indicator mean years of schooling is slightly higher in Belarus (12.3 years vs. 12.0 years), and a second indicator, expected years of schooling, is equal in both countries (15.5 years). The main indicator determining the higher rank for Russia is income: Russian gross national income (GNI) per capita is $\$ 24,233$ while Belarusian GNI is only $\$ 16,323$. On the basis of this source, we conclude that Belarus and Russia have similar ratings and educational potential in their human development. However, these two indicators do not provide the whole picture of the situation in HES.

Another important indicator of educational success is the number of students, i.e. a factor that depends on demographics. In general, demographic trends in Russia and Belarus are similar, but the size of the population of the two countries is not compatible nor is their ethnic composition. For economic reasons, ex-Soviet migrants mainly go to Russia. These factors influence the birth rate and indirectly the sphere of higher education. Due to the demographic situation, the number of students is decreasing in both countries.

Official statistics in Belarus differ in Russia for educational indicators; some indicators are not measured, even if they are in use in international statistics. For example, there is no enrollment rate in the age range of 18-34 years. Some important information is not available due to transparency issues. In this article we use the available data, although it sometimes cannot provide a fully comparable picture of higher education in Belarus and Russia.

The educational level of youth is more suitable for a comparative analysis than HDI. This indicator is used in many European countries and beyond. In Europe, the proportion of the population that reached the third stage of education (according to the international classification system of education, levels 5-6) in the population of 30-34 years is often considered. In the EU, this share averages $35.8 \%$. In Belarus, national statistics do not use this indicator; according to the calculations, this share is extremely high - around 59\% [Bogdan 2018, p. 582]. However, the share of the state expenses for this level from all expenses for education decreases from year to year. 
In relation to GDP per capita, this share of expenditures in Russia and Belarus is $0.9 \%$, which is significantly lower than in the EU $(1.3 \%)$ or in other highly developed countries. Russia spends a third more on a third-level student than Belarus, although the percentage of gross domestic product (GDP) spent on higher education in Russia and Belarus is almost identical: $14 \%$ and $15 \%$. Today, according to the official calculations, the cost per third-level student in absolute terms in Belarus is $\$ 2,763$, in Russia $-\$ 3,900$ [Bogdan 2018, p. 583], these figures are lower than in the EU. Inadequate funding for higher education at this level can decrease its quality and possibly lead to an outflow of young people to study abroad. Many Russian students study abroad, especially in the US and the EU. For example, only in 2016 there were 10,000 Russian students in Germany, more than 5,000 in the US, more than 4,000 in the UK, and 3,600 in France [Obrazovanie $\mathrm{v}$ tsifrah 2018, p. 47]. The number of Belarusian students abroad is smaller [Titarenko, Zaslavskaya, Avetisyan, Galikyan, Klimenko, Lebedeva, Melkumyan 2019, pp. 93, 96].

If we compare the number of students in both countries, we can see that it differs greatly: in the 2016/17 academic year, according to published statistics, 4.4 million people were studying in Russia at all levels of higher education, and the state financing of education in total was $3.6 \%$ of GDP. More than $30 \%$ of the population, aged $25-64$, had higher education. Government spending on higher education accounted for $1.6 \%$ of total government spending, or $0.6 \%$ of GDP [Obrazovanie v tsifrah 2018, pp. 11, 12, 16, 22-23]. At the beginning of the 2016/2017 academic year, there were 818 universities in Russia, of which 316 were non-state (almost 39\%) [Obrazovanie v tsifrah 2018, p. 33]. At the beginning of the same year, 3.3 million people were studying in bachelor's programs, 0.7 million people were studying in specialist programs, and 0.4 million people in master's programs [Obrazovanie v tsifrah 2018, p. 44]. In Belarus, the number of students among the young people of this age group is $91.5 \%$ (usually it is a cohort of the 17 -year-olds who graduated from high school the same year). This means that there are practically no barriers to entering universities for school graduates. It is not by chance that, according to the latest data of the World Bank, the rate of school graduates enrolled in Belarusian universities is $87 \%$. Higher education has become publicly available [Spasyuk 2014]. This massification also has negative aspects: it has led to a decrease in the quality of education [Gaisenok 2018].

Belarus reached the peak of the number of students studying in HEIs in the 2011/12 academic year: 445,000 students, or 471 per 10,000 people. This number was almost equally divided between full-time and part-time students. Enrollment in the same year was 100,000 people and then it gradually started to decrease. In the 2016/17 academic year, enrollment was less than 63,000, and there were 313,000 students (330 per 10,000 of the population). During the period from 2010 to 2017 the number of universities decreased slightly: from 55 to 51 (due to the closure of several nongovernmental institutions). [Statisticheskij ezhegodnik 2018; Obrazovanie v Respublike Belarus 2017]. In the current academic year, there are 268,000 students. From 2010 to 2018 the number of full-time and part-time students decreased by $40 \%$ and $50 \%$ respectively [Obrazovanie v Respublike Belarus 2018, p. 35].

As the number of young people graduating from high school declined, in order to maintain the number of students the state increased the number of budget places in state universities: from 2010 to 2018 it increased from $33.8 \%$ to $43.8 \%$ [Obrazovanie $v$ Respublike Belarus 2018, p. 40]. Several inefficient universities were closed according to the results of accreditation. Currently, there are 51 HEIs in Belarus (42 state and 
9 private). The Ministry of Education will not reduce this number in the near future in order to ensure access to higher education throughout Belarus. 28 of the 51 HEIs are located in Minsk, where more than half of students study.

University graduates who have been educated on a budget basis receive an obligatory state employment position, like in the USSR, which is not the case in Russia. This is a significant difference between the two countries which is negatively estimated as a relic of the Soviet past by supporters of the liberal approach [Belaya kniga 2018]. The government positively assesses this feature; however, it does not help the country meet global educational challenges.

The proportion of students in different study programs in Belarus differs from Russia: 96.3\% students are in specialist programs, and much are fewer in Master's $(2.3 \%)$ and $\mathrm{PhD}(1.3 \%)$ programs [Belaya kniga 2018, p. 11]. The massification of higher education led to the cancellation of special admission preferences for non-urban students in Belarus: these preferences caused a significant general decrease in the overall level of applicants' Asian knowledge [Gaisenok 2018]. The admission procedure differs in the two countries: in Russia all students take the unified state exam (USE) which serves as a school leaving and university entrance exam. In Belarus, there are also final exams at high school; however, those planning to continue their education have to take the Centralized Tests (CT) in 3 or 4 school subjects depending on their application to a particular HEI. This difference means there is no possibility for Russian graduates to be accepted for free education in Belarus HEIs if they do not pass CTs, and vice versa. That is why most Russian students pay for their study in Belarus.

Other changes include the assessment systems ( 5 bands in Russia and 10 in Belarus), and the type of degrees. The Bachelor's degree does not exist in Belarus, however, specialist study programs are only 4 years (with rare exception); in Russia Bachelor's programs last 4 years and specialist programs last 5 years.

\section{Regionalism in Education}

The number of foreign students in Russia and Belarus also differs and reflects their different economic and political roles in the region and the world. Russia ranks seventh in the world in the global education market in this aspect. According to the data for the 2016/17 academic year, there were over 313,000 foreign students, which was 5.7\% of the total number of students in Russia. Russia cannot be compared with the leader in the global education market of the USA with a share of foreign students of about $20 \%$ [Aref'ev 2018, p. 305], but in the Eastern European region, no country can compete with Russia. The average annual rate of increase in the number of foreign students over the past 10 years was $9.6 \%$ [Aref'ev 2018, p. 319]. The fact that the first four countries sending students to Russian universities are located in the Asian region means that the Asian direction has become dominant in Russia's foreign education policy. Judging by the development trends of educational regionalism, this direction is unlikely to change in the coming years. Until recently, the increase in foreign students in Russia came mainly from post-Soviet countries. From the 2004/05 to 2016/17 academic years, these countries accounted for $75 \%$ of the total growth of full-time foreign students and $100 \%$ of part-time foreign students in Russia. The leaders in this group were Kazakhstan (more 
than $20 \%$ of all foreign students in Russia) and Turkmenistan (just under 9\%), Belarus was seventh (4.2\%). Some changes in this hierarchy are possible because the number of the Ukrainian students in Russia has recently declined (for Belarus, the number of the Ukrainian students has never been significant).

The main donor countries outside the post-Soviet region are China $(8.7 \%$ of all students in the 2016/17 academic year) and India (3.1\%) [Aref'ev 2018, p. 313]. Most foreign students study at Bachelor's and specialist levels. A significant proportion of foreign students in Russia are studying engineering or medicine. Their common problem, often leading to dissatisfaction with the education they receive, is poor knowledge of Russian (recently it has become a problem for students from some post-Soviet countries), which inevitably affects the quality of education [Aref'ev 2018, p. 320].

Belarus aims at a multi-vector internationalization of education, however, in reality the Asian vector prevails, similarly to Russia. The total number of foreign students is much smaller, and it is growing more slowly than in Russia. In the 2010/11 academic year there were 9,357 such students in Belarus, and 15,506 in 2018/19. Half of these students were from Turkmenistan, 9\% from Russia, 7.2\% from China. This hierarchy has changed during these years. In 2010 the number of Russians was $23.5 \%$, Turkmen $36.4 \%$, Chinese $-13.1 \%$. Recently a significant shift towards the East has taken place. The total number of foreign students accounted for $5.8 \%$ of the total number of students in the Republic of Belarus [Obrazovanie v Respublike Belarus 2018, p. 41].

Mobility exchange between Russia and Belarus it is not equal, favoring the former. In the 2017/2018 academic year, there were around 1,500 Russian students in Belarus, while the number of Belarusians studying in Russia (mostly as part-time students) was 10 times higher. Student exchanges are more popular in the border regions.

The Asian regional initiative was driven by the economic interests of Belarus: the authorities sought to enlarge their educational market and sell Belarusian educational services to their economic and political partners. Programs in the Russian language make Belarus more attractive for students from ex-Soviet states, who mostly originate from families with a good command of Russian. Moreover, the Republic has a reputation as a safe country which provides foreigners with comfortable conditions for studying. The Belarusian system of higher education is successful among many Asian countries as it provides a relatively good education, especially in medicine, for a moderate price compared to other countries. Turkmenistan and China account for the two largest groups of Asian students (7,200 and 1,400 people respectively). Thanks to bilateral agreements, foreign students are only required to pass an interview to demonstrate their proficiency in Russian, the language of most courses. Preparatory Russian language training is available prior to degree programs [Titarenko 2019, p. 6].

Currently, around $5 \%$ of all students in Belarus are international; therefore, the opportunity for further growth is high. The search for appropriate forms of educational cooperation is continuing. It has been expected that the formation of the Eurasian Economic Union would increase the cooperation in education because this integration can significantly promote Eurasian economic integration. However, this has not happened yet: some members of the Eurasian Economic Union are afraid of a possible brain drain to Russia with a higher level of educational integration within the Union. Several Russian universities have already established bilateral and multilateral Master's programs to train students for employment in the popular spheres of work in the region. This kind of cooperation at inter-university level is on rise, involving new educational 
actors from Russia, and this trend will continue. Unfortunately, Belarusian universities do not participate in this initiative. So far, in regard to Russia and Belarus, both European integration (the Bologna process) and Eurasian integration are less developed than the Asian direction of regional educational initiatives.

Branch campuses as a form of educational cooperation are also more typical for Russia than for Belarus. There are no Russian branches and only two joint BelarusianRussian HEIs in Belarus itself, there are no Belarusian campuses or branches abroad. The main reasons for this policy are economic: a lack of finance for such initiatives and a lack of assurances that they will be profitable for the country. On the contrary, Russia opened several university branches in the post-Soviet region to promote educational internationalization: such branches are considered to be part of the soft power of Russian international foreign policy and a regional integration strategy in global educational competition. Russia is among the top five global exporters of international branch campuses. During the post-Soviet period, 58 branch campuses were established by Russian universities in 12 former Soviet republics [Abbasov 2019, pp. 13-14]. It is clear that Russia took the lead in fostering cooperation and educational integration in the post-Soviet region.

Russia organized a joint educational forum with ASEAN after which the ASEAN-Russia Working Group on Education was launched in 2018 to strengthen cooperation within the ASEAN educational network. In general, Russia "sees itself as an important player in maintaining and extending educational opportunities" [Sabzalieva 2019, pp. 7-8]. It has also been increasing its cooperation with members of the Eurasian Economic Union opening and supporting joint universities in these countries and the regions beyond Eurasia (BRICS, the Global South). Russia has put forward an educational policy goal similar to the EU: to be among the global leaders in the education market.

The unification of educational approaches does not exist in the Union State, therefore educational integration between them is not higher than within the members of the CIS. Students study in neighboring countries anyway and for many personal reasons. If the entrance exams were unified, this level might be much higher; this is an issue of the political will to improve the situation and make the HES in the two countries (and probably in the Eurasian Economic Union) more similar for the benefit of all.

\section{European Integration}

One of the forms of educational integration in Europe is the Bologna system which currently unites 48 countries. It provides a framework for international cooperation between universities and facilitates the dissemination of the best regional experiences in higher education. Because its official goals are the creation of a common space for higher education in Europe and the provision of new opportunities for graduates to be employed in the common EU labor market, the participation of Russia and Belarus in the European space of higher education might potentially increase the brain drain. Therefore, the Bologna system is a challenge as well as an opportunity to improve the quality of education.

Russia entered the Bologna system in 2003, to harmonize with European education standards; Belarus joined it only in 2015 being the last European country to do so. The Bologna reforms were gradually introduced into the Russian HES, starting with the 
3-level structure, so that now there are levels of Bachelor's, Master's and PhD studies. "Specialists" also exist, but they are a minority. In Belarus, Bachelor's degrees do not exist: graduates from the 4-year education are called specialists - similar to the previous stage of the 5-year education. In 2019, the Belarusian Ministry of Education decided to reduce Master's programs from two to one year, with a significant proportion of distance classes. The Belarusian academic public accepted this change, because students' motivation to continue their education immediately increased. According to our survey results (2019), they did not want to spend two years on Master's studies. According to the expert interviews, it is not at all clear for the university staff what the principal differences between the courses at the first and second levels of higher education are, and how to control and check independent student work at the Master's level. Lack of experience has meant many teachers reached a deadlock - similar to the one experienced by Russian university staff in the early 2000s, after the introduction of the Bologna system [Zborovsky 2018, p. 99]. If so, the implementation of the Bologna innovations would also take more time before they bring visible results. Currently, there is a concern that the shortening of Master's programs to one year could make the two-level structure of higher education similar to the previous 5-year education model and practically prevent the renovation of the old system of higher education. More importantly, this is not a solution for another problem - lack of the student motivation. This question leads to the high school system and its similar problems of motivation and the quality of education. According to Zborovsky, it is necessary to search for "new learning technologies that would allow students to be interested more and more than today in reaching the goal of education of specific social and professional positions" [Zborovsky 2018, p. 100]. Still, it is obvious that as long as the knowledge students receive is not closely correlated with future income and a professional career, motivation will be low regardless of educational structures.

There are other concerns from both countries related to the implementation of the Bologna principles. For example, student mobility depends on the quotas given to the country and on the financial resources of the students' families. The economic conditions in Belarus and in many provincial Russian cities mean that many students cannot afford such mobility. Russian scholars are concerned about the poor finances of provincial universities [Zborovsky, Ambarova 2019], while the level of participation in the mobility programs run by the Russian Ministry of Education and Science with full support, is small [Poleshchuk, Ridiger 2018]. In Belarus, according to the expert interviews, for financial reasons it is becoming difficult to find students ready for long-term mobility. What is more important, staff knowledge of the Bologna principles is poor in both countries, as is student knowledge [Motova 2018; Titarenko, Zaslavskaya, Avetisyan, Galikyan, Klimenko, Lebedeva, Melkumyan 2019]. The national structure of qualifications is not in harmony with the new structure of education, so that a second level degree does not guarantee a better job or a higher salary [Motova 2018; Belaya kniga 2018].

The attitudes of academic staff in Belarus differ slightly. If in Russia there is no consensus amongst the scholars whether the move to a 3-level HES has been justified, in Belarus the governmental decisions on this matter have been accepted without public discussion. In 2018, the official assessment of the implementation of the Bologna principles was recognized by the Ministry of Education as successful. The liberal assessment of the same processes was very critical and revealed many problems [Belaya kniga 2018]. It is interesting to note that in Russia critical assessment of the same process is not 
a rare thing - after more than 15 years of belonging to the Bologna system [Baydenko 2018; Motova 2018]. For Belarus and Russia, the major Bologna principles seem to be the new architecture of education, academic mobility, academic freedoms, and ECTS (European Credits Transfer System). Russia is far ahead of Belarus in the introduction of the three-level structure and academic mobility; ECTS are introduced in both countries, however, there are many problems related to the alignment of educational systems such as academic rights and freedoms, the recognition of qualifications, and quality assurance [Romanova, Erdakova, Maznichenko 2018, p. 34].

The issue of quality assurance is also topical. This is connected not only to the accreditation of HEIs (and the right of the state to close any HEI with a low quality of education). According to the opinion of many scholars, the selected quality assessment methods are subordinated to future employer expectations (their desire to employ graduates with the particular practically oriented knowledge, competences and skills) [Glebova, Gus'kova 2012, pp. 2-5]. In a number of cases, these expectations do not correspond to educational programs and generate contradictions of both a substantive and methodological nature. However, there are no universal methods of quality management which would satisfy both HEIs and businesses.

One more benefit offered by the European Higher Education Area is the possibility to establish double degree programs. Such programs allow students to obtain two degrees from partner universities in two countries. Russia is very active in such practice, although there are numerous financial and formal obstacles for the proper implementation of these initiatives. In Belarus this practice has just started: for example, in 2019 the first group of Belarusian State University students received double Master's degrees from BSU and Hochschule Mittweida, Germany in applied economics. However, there are no double degree programs within the Eurasian educational space. This is one reason why highly motivated Belarusian students from middle class families prefer to study abroad (at Bachelor's and Master's levels). It seems that economic conditions raise many obstacles for the better implementation of best practices from abroad because the HES needs better financing and more international opportunities.

The issues of the quality of education and student motivation remain major problems in both countries regardless of their efforts to find solutions. A radically new approach was recently introduced: the model of "university 3.0" to digitize educational modernization. For the successful mass implementation of this model, a radical break with the Soviet educational heritage will be required. Some scholars stress that modern technologies provide new opportunities for economic growth and competitiveness in a global world. From their perspective, this historical moment of changing the technological basis of a society can help both Russia and Belarus reach an advanced level instead of just catching up with the West [Sirenko, Malinetsky 2019, p. 554]. The introduction of digital methods in education can help to prepare students for employment in the digital economy. Currently, Belarusian state policy in higher education is more and more oriented to the labor market and the model of "university 3.0". This way, the system tries to react to the new demands of the global labor market. The main mechanisms to realize this goal include opening new specializations and updating educational programs. Entrepreneurial universities are a new mechanism to reach the same economic goals and prepare more specialists for the digital economy.

The introduction of "university 3.0" is growing in both countries; it aims to increasing the competitiveness of HES. There is also a concern in Russian academia 
that radical reforms may bury academic freedoms and subordinate the whole sphere of education to economic needs. If this trend continues, the Russian HES can reach this goal earlier than Belarus, although this has just started and "mainly affects a handful of leading universities" [Chepurenko 2018, p. 31].

Inter-country educational cooperation, the creation of large education hubs and the decentralization of higher education can be more effective for the development of the HES in Russia and Belarus. Moscow State University has already gone this way, and there are a few other universities in Russia which have developed good ties with the market while keeping their academic culture valid. Some scholars stress that if the development of HES in Russia or Belarus follow this path, it will be necessary to decentralize the whole HES [Rudskoy, Borovkov, Romanov, Kolosova 2019, p. 16]. According to these views, decentralization will allow some universities to develop a corporate model, while other universities will not be involved in such practice.

\section{Conclusion}

HES in Russia and Belarus are still based on their common Soviet heritage, although during the last decades they have experienced significant changes. They have more features in common, regardless of some significant peculiarities in each of them. They are similar in the basic approaches to higher education (centralized control, state-approved educational standards and programs, the combination of the education and upbringing of youth), with various differences in particular issues (admission systems, grades, exams, tuition costs, and the placement of graduates).

Comparing the development of higher education in the two countries, one can assume that the Russian HES is more effective in the global competition: several Russian universities have high world rankings and attract a lot of foreign students. Belarusian HES cannot attract the best staff and students on the same level, as it has much less state finance - its principal investor. Only one Belarusian university was included in the best 500 universities according to QS World University Rankings. Only recently such issues as the diversification of funding and the development of an entrepreneurial culture were included on the agenda in Belarus.

Highly centralized control slows down the transformation and adjustment of HES to the needs of the digital economy.

While contemporary approaches to the modernization of HES differ in Belarus and Russia, the two share similarities that set them apart from other countries. Most importantly, both countries provide unyielding support for their national priorities in higher education even if it prevents the implementation of the Bologna principles or their own declarations about unified approaches to education within the Union State. When developing their foreign educational policies, both countries are "moving East": most foreign students in both countries are from the Asian region. European educational integration is still important for the alignment of the HES structure and increasing the competitiveness, but it is not promising for recruiting students from the EU. Finally, as both countries belong to the same Eurasian region and are trying to increase economic integration within the Eurasian Economic Union, they face common challenges and therefore in the nearest future they may continue to have more similarities than differences. 


\section{References}

Abbasov A. (2019) Emergence of Russian Branch Campuses in the Post-Soviet Space as Regional Integration Strategy. Higher Education in Russia and Beyond, no 1, pp. 13-14.

Akhlestina A., Erstein L. (2019) Formalizatsiya kak prichina razrusheniya vysshego obrazovaniya $\mathrm{v}$ Rossii [Formalization as a Reason of Destruction of Higher Education in Russia]. Alma Mater, no 3, pp. 84-88.

Aref'ev A.L. (2018) Mezdunarodnoe obrazovanie v global'nom i rossijskom izmerenii [International Education in Global and Russian Dimensions], Obrazovanie i nauka v Rossii: sostoyanie i potentsial razvitiya, vyp. 3 [Education and Science in Russia: State and Development Potential. Issue 3], Moscow: Ministerstvo Nauki I Vysshego Obrazovaniya Rossiyskoj Federatsii, pp. 301-327.

Baidenko V.I. (2018) Bolonskij protsess: v preddverii tret'ego desyatiletiya [Bologna Process: at the Threshold of the Third Decade]. Higher Education in Russia, vol. 27, no 11, pp. $136-148$.

Belaya kniga 2018. Evropejskie perspektivy belaruskogo vysshego obrazovaniya [White Book 2018 European Perspectives of Belarusian Higher Education] (2018), Vilnius: VŠI «Socialinès ir politinės ekspertizès agentūra».

BGU v mirovykh rejtingakh [Belarusian State University in World Rankings] (2018). Belarusian State University. Available at: https://www.bsu.by/main.aspx?guid=146761, accessed 31.08.2019.

Bogdan N.I. (2018) Obrazovanie i nauka dlya innovatsionnogo razvitiya stran EAES: sravnitel'naya otsenka [Education and Science for the Innovation Development of the EAEU Members: Comparative Assessment]. Bol'shaya Evraziya: razvitie, bezopasnost', sotrudnichestvo.Ezhegodnik. Vypusk 1. Chast' 1 [Greater Eurasia: Development, Security, Cooperation. Yearbook. Issue 1. Part 1] (ed. Gerasimov V.I.), pp. 582-585.

ChepurenkoA.Yu. (2018) Marks v universitete 3.0? [Marx in the University 3.0?]. Sotsiologicheskie issledovaniya, no 5, pp. 26-34.

Froumin I., Kouzminov Y., Semyonov D. (2014) Institutional Diversity in Russian Higher Education: Revolutions and Evolution. European Journal of Higher Education, vol. 4, no 3, pp. 209-234.

Gaisenok V.A. (2018) Systema vysshego obrazovaniya v Respublike Belarus': etapy razvitiya i tekushchie zadachi [System of Higher Education in the Republic of Belarus: Development Stages and Current Tasks]. Vysshaya shkola: opyt, problemy, perspektivy. Chast' 1 [Higher Education: Experience, Problems, Prospects. Part 1. Moscow: RUDN, pp. 23-26.

Gille-Belova O. (2015) Beyond the Limits of the European Higher Education Area: The Case of Belarus. European Journal of Higher Education, vol. 5, no 1, pp. 83-95.

Glebova L.N., Gus'kova M.V. (2012) Podkhody k formirovaniyu nezavisimoj otsenki kachestva professional'nogo obrazovaniya [Approaches to the Formation of the Independent Assessment of Professional Education]. Vysshee obrazovanie segodnya, no 4, pp. 2-5.

Gotovnost' belaruskogo vysshego obrazovaniya k vstupleniyu v EPVO. Alternativnij doklad [Belarussian Higher Education: Readiness to EHEA Admission. Alternative Report] (2014). Independent Bologna Committee, Minsk: IBK.

Huisman J., Meek V.L., Wood F.Q. (2007) Institutional Diversity in Higher Education: A Cross-National and Longitudinal Analysis. Higher Education Quarterly, vol. 61, no 4, pp. 563-577.

Huisman J., Smolentseva A., Froumin I. (eds.) (2017) 25 years of Transformations of Higher Education Systems in Post-Soviet Countries: Reforms and Continuity, London: Palgrave Macmillan.

Human Development Reports (2018). United Nations Development Programme. Available at: http://hdr.undp.org/en/2018-update, accessed 31.08.2019.

Kirvel Chs. (2018) Sovremennoe obrazovanie «V tiskakh» liveral'no-rynochnogo extremizma [Modern Education "in the Clutches" of Liberal Market Extremism]. Sociology, no 4, pp. 88-96. 
Kodeks Respubliki Belarus ob obrazovanii [Code of Republic of Belarus about Education] (2011). Available at: www.pravo.by/webnpa/text.asp?RN=hk1100243, accessed 31.08.2019.

Kuzminov Y., Semyonov D., Froumin I. (2013) Struktura vuzovskoj seti: ot sovetskogo k rossijskomu master-planu [HEIs Network Structure: From Soviet to Russian Masterplan]. Voprosy obrazovania, no 4, pp. 8-63.

Motova G.N. (2018) Dvojnye standarty garantii kachestva obrazovaniya: Rossiya v Bolonskom protsesse [Double Standards of Quality Assurance in Education: Russia in the Bologna Process]. Higher Education in Russia, vol. 27, no 11, pp. 9-21.

Novik E.K. (2018) Sotsial'no-gumanitarnoe znanie i obrazovanie: paradoksy razvitiya [Sociohumanitarian Knowledge and Education: Development Paradoxes]. Sociology, no 1, pp. $105-112$.

Obrazovanie v Respublike Belarus' (2018/2019 uchebnij god) [Education in the Republic of Belarus (2018/2019 academic year)] (2018), Minsk: National Statistical Committee.

Obrazovanie v Respublike Belarus' [Education in the Republic of Belarus] (2017), Minsk: National Statistical Committee.

Obrazovanie v tsifrakh: kratkij statisticheskij sbornik [Education in Figures: Brief Statistical Compilation] (2018), Moscow: HSE.

Poleshchuk O.D., Ridiger A.V. (2018) Opyt realizatsii programmy vneshnej mezhdunarodnoj akademicheskoj mobil'nosti minobrnauki Rossii [Experience in Implementing the Program of Foreign International Academic Mobility of the Ministry of Education and Science of Russia]. Obrazovaniye $i$ nauka $v$ Rossii: sostoyanie $i$ potentsial razvitiya. Vypusk 3 [Education and Science in Russia: State and Development Potential. Issue 3], Moscow: Ministry of Science and Higher Education of Russian Federation, pp. 402-408.

Reyting natsional'nykh system vysshego obrazovaniya [Rating of National Higher Education Systems] (2018). Gumanitarnye tekhnologii. Available at: https:/gtmarket.ru/ratings/u21-ranking-of-national-higher-education-systems/info, accessed 31.08.2019.

Romanova G.M., Erdakova V.P., Maznichenko M.A. (2019) Realizatsiya akademicheskikh prav studentov: Rossiya v Bolonskom protsesse [Realization of Academic Rights of Students: Russia in the Bologna Process]. Higher Education in Russia, vol. 28, no 1, pp. 34-45.

Rudskoy A.I., Borovkov A.I., Romanov P.I., Kolosova O.V. (2019) Puti snizheniya riskov pri postroenii v Rossii tsifrovoj ekonomiki. Obrazovatel'nyy aspect [Ways to Reduce Risks When Building a Digital Economy in Russia. Educational Aspect]. Higher Education in Russia, vol. 28, no 2, pp. 9-22.

Sabzalieva E. (2019) Looking East: Russian Regional Educational Cooperation with Asia. Higher Education in Russia and Beyond, no 1, pp. 7-8.

Sirenko S.N., Malinetsky G.G. (2019), Obrazovanel'niy vyzov I modernizatsiya soyuznogo gosudarstva: vozmozhnosti operezhayushego obrazovaniya [Educational Challenge and Modernization of the Union State: Opportunities of Leading Education]. Bol'shaya Evraziya: razvitie, bezopasnost', sotrudnichestvo.Ezhegodnik. Vypusk 2. Chast' 1 [Greater Eurasia: Development, Security, Cooperation. Yearbook. Issue 2. Part 1] (ed. Gerasimov V.I.), pp. 554-559.

Spasyuk E. (2014). Belorusskoye vyssheye obrazovaniye: Pochemu kolichestvo ne perekhodit v kachestvo? [Belarusian Higher Education: Why Does not Quantity Go into Quality?]. TUT.by, November 18, 2014. Available at: https://news.tut.by/society/424109.html, accessed 31.08.2019.

Statisticheskij yezhegodnik Respubliki Belarus' [Statistical Yearbook of the Republic of Belarus] (2018), Minsk: National Statistical Committee.

Titarenko L. (2019) Higher Education Regionalism in Belarus: Variety of Initiatives and Arrangements. Higher Education in Russia and Beyond, no 1, pp. 6-7.

Titarenko L.G., Zaslavskaya M.I., Avetisyan P.S., Galikyan G.E., Klimenko V.A., Lebedeva E.V., Melkumyan Yu.G. (2019) Modernizatsiya system vysshego obrazovaniya Belarusi I Armenii v kontekste processov Evraziyskoy I Evropeyskoy integratsii [Modernization of the Systems of Higher Education in Belarus and Armenia in the Context of the European and Eurasian Integrations], Minsk: BSU.

Vetokhin S. (2001) Reformirovanie vysshego obrazovaniya v Respublike Belarus [The Reforms of the Higher Education in the Republic of Belarus], Minsk: BSU. 
Zakon Respubliki Belarus «Ob Obrazovanii» [Law of Republic of Belarus on Education] (1991). Available at: http://pravo.levonevsky.org/bazaby/zakon/text39/index.htm, accessed 31.08.2019.

Zborovsky G.E. (2018) Modernizatsiya obrazovaniya skvoz' prizmu sotsial'noj politiki [Modernization of Education through the Prism of Social Policy]. The Journal of Social Policy Studies, vol. 8, no 1, pp. 87-104.

Zborovsky G.E., Ambarova P.A. (2019) Mechta o khoroshem obrazovanii: protivorechiya razvitiya obrazovatel'nykh obshchnostej $\mathrm{v}$ rossiyskikh universitetakh [The Dream of Quality Education: Contradictions in the Development of Educational Communities in Russian Universities]. Mir Rossii, vol. 28, no 2, pp. 98-124.

\title{
Системы высшего образования в России и Беларуси: сравнительный подход
}

\author{
Л.Г. ТИТАРЕНКО*
}

\begin{abstract}
*Лариса Григорьевна Титаренко - доктор социологических наук, профессор, кафедра социологии, Белорусский государственный университет; ассоциированный сотрудник, Социологический институт РАН. Адрес: Республика Беларусь, 220030, Минск, пр. Независимости, д. 4. E-mail: larisa166@mail.ru

Цитирование: Titarenko L. (2019) Higher Education Systems in Russia and Belarus: A Comparative Approach. Mir Rossii, vol. 28, no 4, pp. 112-127. DOI: $10.17323 / 1811-038 \mathrm{X}-2019-28-4-112-127$
\end{abstract}

Проблема модернизации высшего образования в России и Беларуси является попрежнему актуальной, несмотря на многочисленные изменения, внесенные в системы высшего образования обеих стран в постсоветский период. Цель статьи показать сходство и различия в практике развития систем высшего образования России и Беларуси. Анализ базируется на статистических материалах развития высшего образования двух стран, изучении литературы, эмпирических данных опросов студентов и материалах качественного исследования в Беларуси, проведенного методом глубинных экспертных интервью в 2018 г.

Отправной точкой высшего образования для обеих стран служила советская модель, но со временем каждая из них стала развивать это наследие по-своему. Несмотря на наличие общих черт в организации и управлении высшим образованием, в настоящее время эта сфера в Беларуси отличается более высокой централизацией управленческих решений и их реализации на практике, чем в России. Централизм находит выражение в большем единообразии образовательных программ, вузовской практики и в директивном принятии решений.

В статье показано, что в российском высшем образовании быстрее идет процесс регионализации, проявляющийся в активном привлечении иностранных студентов. В Беларуси подобные процессы имеют сходный вектор, однако идут присходят медленнее. Обе страны не желают отказываться от национальных 
приоритетов при внедрении Болонских принципов, при этом уровень имплементации Болонских реформ в России выше. Независимо от изменений в архитектуре высшего образования, проблемы его качества и мотивации студентов остаются в повестке дня до сих пор.

Вполне очевидно, что белорусская модель централизации системы высшего образования несколько отличается от российской. Обе страны находятся в ситуации поиска ответов на глобальные вызовы, адаптированные к их национальным социально-экономическим и политическим условиям. Делается вывод, что Россия и Беларусь объективно заинтересованы в изменениях систем высшего образования, которые будут способствовать эффективному развитию этих стран.

Ключевые слова: высшее образование, реформы, Российская Федерация, Республика Беларусь, регионализм, интеграция

\section{Литература}

Арефьев А.Л. (2018) Международное образование в глобальном и российском измерении // Образование и наука в России: состояние и потенциал развития. Вып. 3. Москва: Мин-во науки и ВО РФ. С. 301-327.

Ахлестина А., Эрштейн Л. (2019) Формализация как причина разрушения высшего образования в России // Алма Матер. № 3. С. 84-88.

Байденко В.И. (2018) Болонский процесс: в преддверии третьего десятилетия // Высшее образование в России. Т. 27. № 11. С. 136-148.

БГУ в мировых рейтингах (2018) // Белорусский государственный университет // https://www.bsu.by/main.aspx?guid=146761

Белая книга 2018. Европейские перспективы беларуского высшего образования (2018). Вильнюс: VS̆ $I$ « Socialinès ir politinès ekspertizès agentūra».

Богдан Н.И. (2018) Образование и наука для инновационного развития стран ЕАЭС: сравнительная оценка // Герасимов В.И. (ред.) Большая Евразия: Развитие, безопасность, сотрудничество. Ежегодник. Вып. 1. Ч. 1. С. 582-585.

Ветохин С. (2001) Реформирование высшего образования в Республике Беларусь. Минск: БГУ.

Гайсенок В.А. (2018) Система высшего образования в Республике Беларусь: этапы развития и текущие задачи // Высшая школа: опыт, проблемы, перспективы: материалы XI Междунар. научно-практ. конф., Москва, РУДН, 29-30 марта 2018 г.: в 2 ч. Ч. 1. Москва: РУДН. С. 23-26.

Глебова Л.Н., Гуськова М.В. (2012) Подходы к формированию независимой оценки качества профессионального образования // Высшее образование сегодня. № 4. С. 2-5.

Готовность беларуского высшего образования к вступлению в ЕПВО. Альтернативный доклад (2014) // Независимый Болонский Комитет. Минск: НБК.

Закон Республики Беларусь «Об образовании» от 29.10.1991 №1202-XII // http://pravo.levonevsky.org/bazaby/zakon/text39/index.htm

Зборовский Г.Е. (2018) Модернизация образования сквозь призму социальной политики // Журнал исследований социальной политики. Т. 8. № 1. С. 87-104.

Зборовский Г.Е., Амбарова П.А. (2019) Мечта о хорошем образовании: противоречия развития образовательных общностей в российских университетах // Мир России. Т. 28. № 2. С. 98-124.

Кирвель Ч. (2018) Современное образование «в тисках» либерально-рыночного экстремизма // Социология. № 4. С. 88-96. 
Кодекс Республики Беларусь об образовании (2011) // http://www.pravo.by/document/?guid=3871\&p0=hk1100243

Кузьминов Я., Семенов Д., Фрумин И. (2013) Структура вузовской сети: от советскому к российскому мастер-плану // Вопросы образования. № 4. С. 8-63.

Мотова Г.Н. (2018) Двойные стандарты гарантии качества образования: Россия в Болонском процессе // Высшее образование в России. Т. 27. № 11. С. 9-21.

Новик Е.К. (2018) Социально-гуманитарное знание и образование: парадоксы развития // Социология. № 1. С. 105-112.

Образование в Республике Беларусь (2018/2019 учебный год) (2018). Минск: Национальный статистический комитет.

Образование в Республике Беларусь. Статистический сборник (2017). Минск: Национальный статистический комитет.

Образование в цифрах. Краткий статистический сборник (2018). М.: ВШЭ.

Полещук О. Д., Ридигер А.В. (2018) Опыт реализации программы внешней международной академической мобильности минобрнауки России // Образование и наука в России: состояние и потенциал развития. Вып. 3. Москва: Мин-во науки и высшего образования РФ. С. 402-408.

Рейтинг национальных систем высшего образования (2018) // Гуманитарные технологии // https://gtmarket.ru/ratings/u21-ranking-of-national-higher-education-systems/info

Романова Г.М., Ердакова В.П., Мазниченко М.А. (2019) Реализация академических прав студентов: Россия в Болонском процессе // Высшее образование в России. Т. 28. № 1. С. 34-45.

Рудской А.И., Боровков А.И., Романов П.И., Колосова О.В. (2019) Пути снижения рисков при построении в России цифровой экономики. Образовательный аспект // Высшее образование в России. Т. 28. №2. С. 9-22.

Спасюк Е. (2014) Белорусское высшее образование: Почему количество не переходит в качество? // TUT.by. 18 ноября 2014 // https://news.tut.by/society/424109.html

Сиренко С.Н., Малинецкий Г.Г. (2019) Образовательный вызов и модернизация союзного государства: возможности опережающего образования // Герасимов В.И. (ред.) Большая Евразия: Развитие, безопасность, сотрудничество. Ежегодник. Вып. 2 Часть 1. М.: ИНИОН. С. 554-559.

Статистический ежегодник Республики Беларусь (2018). Минск: Национальный статистический комитет.

Титаренко Л.Г., Заславская М.И., Аветисян П.С., Галикян Г.Э., Клименко В.А., Лебедева Е.В., Мелкумян Ю.Г. (2019) Модернизация систем высшего образования Беларуси и Армении в контексте процессов Евразийской и Европейской интеграции. Минск: БГУ.

Чепуренко А.Ю. (2018) Маркс в университете 3.0? // Социологические исследования. № 5. C. 26-34.

Abbasov A. (2019) Emergence of Russian Branch Campuses in the Post-Soviet Space as Regional Integration Strategy // Higher Education in Russia and Beyond, no 1, p. 13-14.

Froumin I., Kouzminov Y., Semyonov D. (2014) Institutional Diversity in Russian Higher Education: Revolutions and Evolution // European Journal of Higher Education, vol. 4, no 3, pp. 209-234.

Gille-Belova O. (2015) Beyond the Limits of the European Higher Education Area: The Case of Belarus // European Journal of Higher Education, vol. 5, no 1, pp. 83-95.

Huisman, J., Meek V.L., Wood F.Q. (2007) Institutional Diversity in Higher Education: A Cross-National and Longitudinal Analysis // Higher Education Quarterly, vol. 61, no 4, pp. 563-577.

Huisman J., Smolentseva A., Froumin I. (eds.) (2017) 25 years of Transformations of Higher Education Systems in Post-Soviet Countries: Reforms and Continuity, London: Palgrave Macmillan.

Human Development Reports (2018) // United Nations Development Programme // http://hdr.undp.org/en/2018-update

Sabzalieva E. (2019) Looking East: Russian Regional Educational Cooperation with Asia// Higher Education in Russia and Beyond, no 1, pp .7-8.

Titarenko L. (2019) Higher Education Regionalism in Belarus: Variety of Initiatives and Arrangements // Higher Education in Russia and Beyond, no 1, pp. 6-7. 